\title{
RECENT DUTCH AND BELGIAN APPROACHES TO ETHNICITY IN AFRICA
}

\section{Kees SCHILDER \& Wim VAN BINSBERGEN}

African Studies Centre, P.O. Box 9555, 2300 RB Leiden, The Netherlands/

Vakgroep Culturele Antropologie/Sociologie der Niet-westerse Samenlevingen, Vrije Universiteit, Amsterdam

\section{SUMMARY}

The papers in the present special issue of Afrika Focus are discussed from a comparative and theoretical perspective, which highlights the shortcomings of current approaches to African ethnicity on two counts: the assumption that ethnicity is a colonial creation, and the over-emphasis on political manipulation. The papers here presented suggest that there is a case for a re-assessment of the limits to ethnic manipulation, and the exploration of the explanatory value of local cultures considered over considerable time periods.

KEY WORDS: ethnicity, Africa, colonialism, culture

The papers presented in this special issue on ethnicity of the review Afrika Focus form a selection of the contributions to the two-days' Workshop on Ethnicity in Africa, which the editors organised at the African Studies Centre, Leiden University, December 12-13, 1991. While major responsibility, both financially, logistically and conceptually, for the workshop lay with the African Studies Centre,(1) it reflected a combined initiative from the Netherlands Association of African Studies and its Belgian sister, the Belgian Association of Africanists. One of our aims was to bring together Africanist scholars working in the Netherlands and Belgium who were either focusing on ethnicity in their current research, or cs who could be persuaded to present, from the perspective of ethnicity, research data which they had collected with a different emphasis in mind. In this way we sought to perpetuate a tradition which had led to inspiring similar Dutch-Belgian encounters in 1981 and 1984.(2) Of course, our hidden agenda was to stimulate 
more Dutch and Belgian colleagues to join the international expansion of ethnic studies in recent years. Furthermore we considered it useful to make a link, in the programme of the Workshop, with related fields of studies which - more than African ethnicity - had moved to the centre of social scientists' attention in both countries:

(a) the recent outburst of ethnic tensions in Eastern Europe (associated with violent conflict and the disintegration of states), and

(b) growing ethnic tensions in Western Europe as a result of a massive influx of migrants since the 1960 s, associated with the colonial heritage and with labour migration from the Mediterranean region.

We hoped that African models of ethnicity could be applied to non-African ethnic conflict situations. In order to accommodate the second topic a lively mini-symposium on global ethnic issues was organised within the workshop. Papers concerning non-African topics could obviously not be included in this special issue, so that the present selection, already kept to a minimum so as to fit the format of this journal, is certainly not a representative reflection of the proceedings of the Workshop itself.(3)

The papers at the workshop presented various aspects of the study of ethnicity. They made it clear that, for the time being, ethnicity does not constitute a main topic in Dutch and Belgian Africanist research. They particularly reflected the paucity of theory formation concerning ethnic processes, and the selection presented here forms hardly an exception. From the Africanist perspective, ethnic studies seem to constitute a vaguely defined field of research, characterised more by a variety of themes and explanatory factors stressed than by a unified theory. For instance, there is still far from agreement as to the distinctive characteristics of the ethnic group. Most commonly, authors refer to: a shared origin or descent, a shared name, culture, religion or language, a habitat, and the consciousness, among the group's members, of belonging (Isajiw 1974; Amselle 1985: 15-19). It is remarkable that the four anthropologists in our small collection (Van Binsbergen, Tiokou, Schilder, De Boeck) emphasise the latter feature, the self-definitional aspect of ethnicity or ethnic identity, whereas the only non-anthropologist, the jurist Beke, especially refers to the 'objective' cultural dimension of ethnicity, notable language, and to descent.

In such a small collection, gaps are inevitable: the production of ethno-histories as a strategy to enhance ethnic group consciousness; urban ethnicity; the role of the Christian missions, education and literacy; the role of kinship and descent in ethnic 
identity formation; gender issues; the role of ethnicity in the wave of democratisation currently flowing over Africa.

Not so much an omission but a matter of deliberate emphasis is the fact that ethnic conflict is not a main topic in the papers. This must be seen as a corrective to the increasingly popular view that ethnicity is synonymous with conflict. It should not be forgotten that, despite such obvious hot spots as South Africa and the Horn, in the majority of African societies more or less peaceful ethnic relations predominate. Nevertheless, conflict is not totally absent in the papers: Beke, Van Binsbergen and Schilder pay attention to the fact that ethnic mobilisation may turn out to be a 'political weapon' in the struggle for realising collective interests (defined as political goals) within the context of the modern state.

The articles represent African countries as far apart as Algeria, Cameroon (twice), Zaire, and Zambia. We regret that for practical reasons no paper on South African ethnicity could be included, despite the fact that such Dutch Africanists as Vernon February (1991).

The classic distinction between a social-structural and a culturalist approach to social reality is prominent in studies of ethnicity in Africa, both in Holland and Belgium, and internationally. Hitherto the former approach has been dominant. This is largely due to the fact that within British social anthropology the study of ethnicity started, in the 1950s (Mitchell 1956; Epstein 1958; Gluckman 1960), as a reaction to the then prevailing functionalism which tended heavily towards culturalism. African societies had been conceived as isolated, integrated and internally structured wholes: as 'tribes'. This postulated social unity was primarily seen as an ideological matter: it was supposed to spring from a system of values and norms shared by all participants - a common culture internalised by all members of society. The classic anthropological monograph was the principal result of this approach. However, soon the one-sided emphasis on culture led to a reaction, mainly from the Manchester school, claiming that it is not so much the norms and values which direct processes of interaction, but micro-political processes, to such an extent that the very norms and values so stressed by the anthropology of an earlier vintage turned out to be rather flexible and manipulative. People do not automatically behave the way they have learned to do: they may either observe norms or ignore or violate them, and in the process they adapt their ideas as to whatever is right, valuable and worth pursuing. In line with this theoretical shift, political determinism has come to form a major tradition in the study of African ethnicity. 
This 'structuralist' tendency in ethnicity studies is reflected in the papers presented here in at least two respects:

(1) The deconstruction of the ethnic group as a group. It was realised that 'the ethnic group' is a mere reification (cf. Fardon 1987). In our scholarly analysis, we should not take at face value the absolute and a-historical meaning which African participants attribute to their 'ethnic group'. These participants' constructs do carry the suggestion that they are static, bounded, solid and unchangeable units (and as van Binsbergen argues in the theoretical part of his contribution this is precisely what makes them effective), but such a participants' view totally ignores the historical dynamics of ethnic identity, and the usually rather vague and blurred boundaries which exist between sets of people designated 'ethnic groups'.

(2) The characterisation of ethnicity as a cultural process primarily determined by an underlying struggle for power. People's ethnic consciousness is pictured as being formed in the course of political confrontation; from this perspective, the study of ethnicity needs to focus primarily on power, group relationships, and structural tensions. The organisational framework for such political struggle is the state; in other words, processes of state formation (as well as its topical complement, state dissociation) 'determine' ethnic consciousness. Historians and anthropologists have situated the emergence of ethnic consciousness within the framework of the colonial state and of Christian mission. Three of our papers (Tiokou, Schilder and van Binsbergen) study ethnicity in the framework of the state, in Cameroon and Zambia respectively; which only leaves out de Boeck, who studies patterns of inter-ethnic interaction at the local level in southwestern Zaire without discussing colonial and post-colonial state influence; and Beke, who does discuss the state in Algeria but does not go into local culture.

What the papers hardly do is problematise the nature and process of the contemporary African state in itself. This is somewhat regrettable, since far from being a fixed and static bedding for the ethnic processes to flow through, the resilience of ethnic phenomena both in contemporary Africa and in the world at large appears to be intimately related to the rapid erosion of the nation state by the combined effects of regional and local pressures on the one hand, the global economy and changing international and intercontinental political order on the other. If wealth flows from the state, ethnicity provides a network to redistribute it; if the state can no longer deliver, ethnicity provides an increasingly important counter-structure for security, distribution, assertion of group rights, etc.

The various papers link the local rural form of ethnicity to processes in the statal domain in various ways. Tioukou stresses the situationality of ethnic identity: it is 
only one level in a hierarchical classification of social identities which converge in each individual. This implies that the nature of local ethnic identity changes at the boundary of the ecological zone in which it has emerged, to such a degree that it tends to conform to the administrative units which were established in the colonial period. Schilder goes into brokerage as the link between the local society and the wider society; it goes together with ethnic ambiguity of the brokers, notably the chiefs, who adopt the dominant religion of the wider society without passing into the dominant ethnic group. Van Binsbergen, while also highlighting the role of ethnic brokers, emphasises the transformation which selected items of the local expressive culture undergo in the process of accommodation to the outside world; a 'traditional' festival is invented because the phenomenon of the festival is an accepted element of the Zambian political culture, and can (in a logic of commoditisation and globalisation) easily be turned into a symbol of local group identity.

Much recent writing on ethnicity in Africa stresses the colonial state as the architect of ethnic groups, via the creation of administrative units which were subsequently labelled in ethnic terms. This approach has emphasised the extent to which ethnic consciousness was externally imposed in a context of unequal power relations. A vocal exponent is Amselle (1985). In his view the advent of the colonial state marked the introduction of ethnic identities in Africa:

'[II] n'existait rien qui ressemblât à une ethnie pendant la période précoloniale. Les ethnies ne procèdent que de l'action du colonisateur qui, dans sa volonté de territorialiser le continent africain, a découpé des entités ethniques qui ont été elles-mêmes ensuite réappropriées par les populations. Dans cette perspective, l' "ethnie" (...) ne serait qu'un faux archaïsme de plus.' (Amselle 1985: 23)

Before that time the only supra-local social identities to exist derived, in Amselle's view, from economic, political, linguistic and culturo-religious group formation, but not from ethnicity in its own right. Thus Amselle radically reverses the view, current especially outside academic circles, according to which ethnic groups are 'traditional' and go back to the pre-colonial past. Ethnic groups then appear as essentially a 'modern' phenomenon, which only emerged in the recent, nineteenthand twentieth century history of Africa. Similar views have been presented by the contributors to Vail's (1989) collection The creation of tribalism in Southern Africa.

What these authors have certainly managed to put across is the insight that ethnic groups and ethnic identities are subject to constant change. A Nkoya today does not have the same ethnic identity as a Nkoya a hundred years ago, and two hundred years ago there were most probably no people identifying as Nkoya at all 
(van Binsbergen 1992a). And even where we can claim a much greater time depth for an ethnonym in itself,(4) this does not mean that the associated ethnic identity would have the same time depth and would have remained constant over that period. Ethnicity is a dynamic process. It may develop towards the stressing of ethnic identities, i.e. an increasing hardening of ethnic boundaries articulated by distinctive markers. Van Binsbergen mentions as a tool the 'invention' of ethnic symbolism, a cultural festival, whereas Beke stresses the role of political parties, which may function as catalysts of a heightened and politicised ethnic solidarity in the context of national politics. Ethnicity may, however, also develop into the direction of ethnic boundary blurring or a weakening of ethnic identities. This is highlighted by the articles of De Boeck and Schilder, which pay attention to the existence of an ethnic twilight zone, which could emerge through the adoption of cultural traits from the wider regional society.

One obvious danger inherent in the view that so-called 'traditional' groups are colonial creations and 'inventions', lies in the absolute passivity which this view attributes to the African population. It implies that ethnicity is merely an 'imposed identity' projected onto Africans from the outside. This is too one-sided to be illuminating, for a number of reasons. First, historical research that goes beyond the colonial and mission archives and seeks to tap oral and written African sources, has brought up too much evidence of pre-colonial ethnic group classifications than that these can be dismissed as mere anachronistic colonial projections. (5) In the same way we would not claim that the ethnonyms as used by Caesar (1986) and Tacitus (1972) in their early descriptions of western and central Europe were, at the time, mere colonial inventions without a social and linguistic basis in the local participants' practice. And even when much of present-day ethnicity in Africa can be shown to be of recent, colonial origin, this should not merely be seen as imposition but also as a local reaction to the effects of colonial and post-colonial administration. The ethnic phenomenon also has an endogenous source, from which the local reactions have been fed; and more often than not this source includes the inspiration, at least, from political and economic group distinctions in the pre-colonial past. In other words, the 'modern' state has been an important factor in twentieth-century ethnicity in Africa, but certainly not the only one. It is our contention that in the current discussion on the dynamics of ethnicity in Africa the formative influence of the colonial (and post-colonial) state is overestimated, at the expense of continuity with pre-colonial processes of group formation. The blanket statement that ethnic groups are ipso facto colonial creations, is wrong: many ethnic groups in Africa have formed before the advent of the colonial state.

It is remarkable that four of the five papers touch on the topic of ethnic or cultural dominance. Ethnic groups carry unequal power in a hierarchically structured 
ethnic field: Arabs versus Berbers, Lozi versus Nkoya, Fulbe versus Mundang. The authors focus on the subordinate ethnic group, and pay to a larger or lesser degree attention to the phenomenon of imposed self-images, which have been (partly) internalised by the subordinate group. De Boeck and Tiokou describe slightly different situations. The Yasa are part of a regional ethnic field along with equal ethnic partners; in the wider society, meanwhile, the Yasa are identified with the Bulu, but this remains underexposed in the article. De Boeck describes a situation where the ethnic group on which his research focuses, the Aluund, is politically dominant, but depends on the ritual authority of another, marginalised ethnic group: a division between political power and healing authority.

Two articles deal with ethnicity in a political context of Muslim dominance. Beke and Schilder describe situations where peripheral ethnic groups, the Berbers and Mundang respectively, adopt Islam without passing into the dominant ethnic group. The Berbers adopted Islam long ago, whereas the islamisation of the Mundang is only in its initial phase. The Mundang have resisted islamisation for a long time, because it went together with a dissociation of one's ethnic group of origin. This was not true for the Berbers. This difference is due to differences in the political context. The effective islamisation of the North African countryside goes largely back to the 12th to 16th centuries, and was effected by popular Sufi orders, which did not threaten local political autonomy: wandering Sufis were incorporated into local culture, and transformed into local saints. (6) The variant of Islam which spread over the northern parts of Nigeria and Cameroon in the 19th and 20th centuries was predominantly infused with the views of state-related ulama instead of Sufis: islamisation took place in the context of migration to Fulbe towns and villages, and incorporation into Fulbe culture of individuals and small kin-groups.

The political situation has recently changed in Algeria. In post-colonial Algeria, the Berbers are increasingly discriminated and exposed to the pressure of arabisation. Beke discusses the recent introduction of a multi-party system in Algeria, and the related politicisation of ethnicity, or ethnicisation of politics. He describes the emergence of several Berber political parties. He shows that the interests of the party leadership are not served by a strongly ethnic image which may deter potential voters among the Arab population. Beke indicates that the Arab-Berber distinction is not that fixed, unchanging and impassable than is often thought. However he does not systematically elaborate on the nature of this ethnic boundary (which is an understudied topic for Algeria). The Arab-Berber distinction is rather an ideological model which is readily available to be put forward or underscored for political purposes (e.g. to emphasise or dissimulate political, economic, or social contradictions in the state arenas). 
Schilder shows that national politics has a regionalist rather than an ethnic bias. In Cameroon, the multitude of relatively small ethnic groups have coalesced into a limited number of regional power blocs. In other African counties, e.g. Nigeria and Kenya, these blocs are characterised by a large degree of ethnicisation through amalgamation: these regional political coalitions developed into new and large-scale ethnic groups. It is well possible that the Berbers are also the result of such a process. This kind of ethnicisation has remained very limited in the power bloc of North Cameroon, since conversion to Islam has not resulted in large-scale ethnic identity change of the populations involved.

In the literature, the role of the elites is usually stressed in ethnicity processes. All papers go into this social stratification aspect of ethnicity. Van Binsbergen pays attention to the cultural creativity potential of the Western-schooled elite members of the Nkoya in western Zambia: they organise a 'traditional' cultural festival in order to enhance the position of the Nkoya at the regional and national ethnic prestige scale. Beke points to the role of the schooled Berber elite in organizing 'modern' political parties in order to enhance Berber political influence. Tiokou refers to the emergence of a national state elite in Cameroon, and suggests that the ethnic identities prevalent in this poly-ethnic class-in-formation tend to be drawn to the background. It should not be ruled out, however, that this has more to do with political ideology than with political practice: it is well-known that ethnic and regional considerations have played an essential role in political appointments (Bayart 1989; Ngayap 1983), although this has largely been denied by the official rhetoric. In the first decades after independence, identification along class-lines was socially much more accepted than affiliation along ethnic lines. The recent upsurge of ethnic tensions in Cameroon in the wake of the introduction of multi-partyism illustrates that ethnic identification has remained an implicit but major concern of the national state elite.

Schilder and (to a more limited degree) De Boeck pay attention to a different type of elite: the chiefs. The former shows that, contrary to the situation in (anglophone) southern Africa (see Vail 1989), the chiefs in North Cameroon, and probably elsewhere in francophone western Africa, are not so much foci of ethnic group formation but centres of ethnic group integration into a Muslim dominated, wider, politico-cultural whole. De Boeck goes into the poly-ethnic composition of the Aluund chiefdoms rather than the external aspects of ethnicity. The dominant ethnic group, which delivers the chiefly title-holder, has not destroyed the ritual sources of authority of the 'incorporated' ethnic groups, but rather integrated them into the politico-ritual system of the polity. It implies that the continued existence of the Chokwe is at least partly based on their continued ritual power in the Aluund chiefdoms. The ethnic distinction is thus related to complementarity: political power excludes certain forms of ritual authority, and vice versa. The 
Mundang chiefdoms, as described by Schilder, on the other hand, are largely mono-ethnic. The Mundang are self-sufficient in the ritual domain; they do not depend on members of other ethnic groups, as the Aluund do. This is due to a different historical development. The autochthonous populations have been assimilated into the conquering ethnic group, the Mundang: they have only 'survived' as distinct clans which still dominate ritual power at the village level of society.

Political determinism in the study of ethnicity has led to an emphasis on the manipulation and changeability of ethnic consciousness, and on the latter's political aspects. More recently we have come to ask ourselves whether there are no systematic limits to this flexibility of the ethnic phenomenon. The papers presented here (with the exception of Beke's) stress the cultural, endogenous side of ethnicity. By implication, they do not seek to 'de-construct', or explain away, ethnicity by reference to reductionist explanations; they take ethnicity as a social fact, constructed by people as all other social facts, and consider the workings of ethnicity - more or less sui generis - in local African societies, rather than remaining fixated on the genesis of the ethnic phenomenon in itself. It is true, of course, that ethnic groups are historical formations which constantly change in response to political and economic circumstances. However, this does not exclude the existence of a relatively persisting core of ethnic consciousness, which has been so much internalised by the majority of the members of a local society that its manipulation (for the sake of political interests) is only possible up to a point. How can we study this a-political core without falling into culturalism, (7) in other words without representing this 'core culture' as a package of primordial sentiments which exist at some exalted plane outside history, and which presumably may be invoked to explain everything without being explained in its turn? The question is whether it is possible to raise the local culture to the status of an explanatory factor in the analysis of ethnicity. This might enable us to do more justice to the emotional overtones which ethnic identity often carries, and which can hardly be accounted for with the instrumentalist approaches which have hitherto dominated the study of African ethnicity. This fundamental theoretical question plays a more or less implicit role in several of the presented papers. Van Binsbergen seeks to link the 'unchangeable' image of ethnicity in the eyes of the participants, to its actual variability over time: ethnic identities then appear as a workable illusion which has become an autonomous force in social reality. De Boeck and Schilder have a cultural focus: they emphasise the potential of the local culture for incorporating outside cultural elements, and look for an explanation in the local culture itself. Schilder stresses that the local cosmology allows for and even encourages the emergence of such ethnic boundary blurring, whereas De Boeck explains its emergence by its potential of solving fundamental contradictions 
within the local cosmology. What is needed is a theoretical model to encompass and explain these variations around a common theme.

This shift in emphasis away from political manipulation advocates a renewed attention for ethnicity outside urban situations or outside social processes which reflect the increasing impact, upon local social formations, of the African state and the world economy. The discussions on the 'crisis of the African state' and on the uncaptured peasantry (as initiated by Hyden 1980; also cf. Hyden \& Bratton 1992) have raised the question whether ethnicity does play a role in the process of by-passing the state which is claimed to be typical of the African countryside in the 1980s and '90s. Can ethnic groups provide an alternative for the state and a mobilisation channel for rural protest movements? Shaw (1986) would answer this question in the affirmative. He sees the countryside as the source of a new form of ethnicity, which is not merely a hangover from urban ethnicity, (8) and therefore does not have to be directed by educated urbanites or returned urbanites. A case in point is van Binsbergen's study of Nkoya ethnicity, where the lack of a secure urban foothold has always prevented the Nkoya from developing urban ethnicity except in the context of strong urban-rural ties which reinforced the attachment to the rural home, and where urbanites, however prominent in contemporary ethnic expressions vis-à-vis the state in the form of the Kazanga festival, are merely the catalysts for a cultural revival which is predominantly rural-based. Also Tiokou and De Boeck clearly show the existence of a rural form of ethnicity, but they stress that it is not articulated to 'modern' state processes, and thus does not develop into a politicised form of ethnicity. Schilder's argument finds itself somewhere in the middle of this range: among the Mundang, chieftainship is the locus of articulation with the outside world, but much of Mundang ethnicity is realised at the clan level in ways hardly dictated by the wider world. These papers, then, call attention to cultural, a-historic, and a-political aspects of ethnicity.

While van Binsbergen's argument opens up to a perspective on globalisation and commoditisation,(9) the other papers explore the rural end of the equation as continuity of rural culture, rather than its erosion by, or manipulative translation towards, the outside world. By suggesting a balance between these two perspectives, which both call to question the earlier fixation on political manipulation, the present collection might constitute a modest yet meaningful addition to the literature on African ethnicity. 


\section{Notes}

1. In this connexion we gratefully acknowledge the essential contributions from the Centre's director, bursar, and administrative staff in general

2. Cf. van Binsbergen \& Hesseling 1984; van Binsbergen et al. 1986.

3. Furthermore, van Binsbergen's paper at the workshop (which was already in press at the time) is not the same as his article in the present issue.

4. As is the case for the Arabs or the North African Berbers - ethnonyms well documented to go back to Antiquity - or the Nigerian Maguzawa, whose name goes back to early Arab contacts (cf. Last 1991).

5. For Zambia, e.g. Derricourt \& Papstein 1977; Papstein 1978; van Binsbergen 1992. For an inspiring collection covering a large part of Africa, e.g. Chrétien \& Prunier 1989.

6. Cf. Schilder 1991 and references cited there.

7. E.g. Geertz 1963; for an effective critique, cf. Doornbos 1972.

8. As has been argued for a long time; cf. Cohen 1974.

9. Commoditization can be said to exist where the production of ethnic symbols in itself takes on the objects, techniques, conventions and - largely capitalist - logic of global processes of production, distribution and organisation, but in an attempt to twist these global processes to local interests; cf. Hannerz 1987; Kopytoff 1986; Colás 1992; Robertson 1990.

\section{References}

Amselle, J.L., 1985, Logiques métisses; Anthropologie de l'identité en Afrique et ailleurs, Paris: Payot.

Bayart, J.F., 1989, L'Etat en Afrique: La politique du ventre, Paris: Fayard.

Beke, D., 1993, 'De Berberse identiteit en het nieuwe meerpartijenstelsel in Algerije', Afrika Focus, nr.1-2, 1993: 125-142 (this issue).

Caesar, 1986, De bello gallico, in: H.J. Edwards, eds., Caesar, The Gallic War, with an English translation, Loeb Classical Library, Cambridge (Mass.): Harvard University Press \& London: Heinemann.

Chrétien, J.-P., \& G. Prunier, réd., 1989, Les etnies ont une histoire, Paris: Karthala/ Agence de Coopération Culturel et Technique (ACCT).

Cohen, A., ed., 1974, Urban ethnicity, London: Tavistock.

ColAs, S., 1992, 'The Third World in Jameson's Postmodernism or the cultural logic of late capitalism', Social Text, 31-32: 258-270.

De Boeck, F., 1993, ' Symbolic and diachronic study of inter-cultural therapeutic and divinatory roles among aLuund ('Lunda') and Chokwe in the Upper Kwaango (South Western Zaire)', Afrika Focus, nr.1-2, 1993: 73-104 (this issue).

Derricourt, R.M., \& R.J. Papstein, 1977, 'Lukolwe and the Mbwela of North-Western Zambia', Azania, 11: 169-175. 
Doornbos, M.R., 1972, 'Some conceptual problems concerning ethnicity in integration analysis', Civilisations, 22, 2: 268-83.

Epstein, A.L., 1958, Politics in an urban African community, Manchester University Press for Rhodes-Livingstone Institute.

Fardon, R., 1987, 'African ethnogenesis: Limits to the comparability of ethnic phenomena', in L. Holy red., Comparative anthropology, Oxford: Basil Blackwell, pp. 168-188.

February, V., 1991, The Afrikaners of South Africa, Londen/Boston: Kegan Paul International. Geertz, C., ed., 1963, Old societies and new states: The quest for modernity in Africa and Asia, New York: Free Press.

Gluckman, M., 1960, 'Tribalism in modern British Central Africa', Cahiers d'Etudes Africaines, 1: 55-70.

Hannerz, U., 1987, 'The world in creolisation', Africa, 57: 546-559.

Hyden, G., 1980, Beyond Ujamaa in Tanzania: Underdevelopment and an uncaptured peasantry, London: Heinemann.

Hyden, G., \& M. Bratton, eds., 1992, Governance and politics in Africa, Boulder/London: Lynne Rienner.

Isajiw, W., 1974, 'Definitions of ethnicity', Ethnicity, 1.

Kopytoff, I., 1986, 'The cultural biography of things: commoditization as process', in: Appadurai, A., ed., 1986, The social life of things: commodities in cultural perspective, Cambridge: Cambridge University Press, pp. 64-91.

Last, M., 1991, 'History as religion: De-constructing the Magians (Maguzawa) of Nigeria Hausaland', paper read at the Colloque International 'Religion et histoire en Afrique sud du Sahara', Centre de Recherches Africaines, Paris, May, 1991.

Mitchell, J.C., 1956, The Kalela dance: Aspects of social relationships among urban Africans in Northern Rhodesia, Manchester: Manchester University Press.

Ngayap, P.F., 1983, Cameroun: Qui governe?, Paris: L'Harmattan.

Papstein, R.J., 1978, 'The Upper Zambezi: A history of the Luvale people 1000-1900', Ph.D. thesis, University of California, Los Angeles.

Robertson, R., 1990, 'Mapping the global condition: Globalization as the central concept', in: M. Featherstone, ed., Global culture: Nationalism, globalisation and modernity, London/Newbury Park: Sage, pp. 15-30.

Schilder, K., 1991, Popular Islam in Tunisia, Leiden: African Studies Centre.

Schilder, K., 1993, 'Local Rulers in North Cameroon: the interplay of politics and conversion', Afrika Focus, nr.1-2, 1993: 43-72 (this issue).

Shaw, T.M., 1986, 'Ethnicity as a resilient paradigm for Africa: From the 1960s to the 1980s', Development and Change, 17, 1: 587-605.

Tacitus, 1972, De origine et situ Germanorum liber, in M. Furhmann, ed., Tacitus Germania, lateinisch und deutsch, Stuttgart: Philipp Reclam.

Tiokou Ndonko, F., 1993, 'Etnicité, nourriture et politique: l'exemple des Yasa de la côte sud du Cameroun', Afrika Focus, nr.1-2, 1993: 105-123 (this issue).

Vail, L., ed., 1989a, The creation of tribalism in Southern Africa, London/ Berkeley \& Los Angeles: Currey/University of California Press.

Vail, L. 1989b, 'Ethnicity in Southern African history', in Vail 1989a: 1-19.

van Binsbergen, W.M.J., 1992, Tears of Rain: Ethnicity and history in central western Zambia, London/New York: Kegan Paul International.

van Binsbergen, W.M.J., 1993, 'Kazanga: Ethnicité en Afrique entre Etat et tradition', Afrika Focus, nr.1-2, 1993: 16-41 (this issue). 
van Binsbergen, W.M.J., in the press, "Minority language, ethnicity and the state in two African situations: the Nkoya of Zambia and the Kalanga of Botswana', paper read at the Workshop on Ethnicity in Africa, Leiden, December 1991; in: R. Fardon \& G. Furniss, réd., Language and languages in Africa [provisional title], in press.

van Binsbergen, W.M.J., \& G.S.C.M. Hesseling (eds), 1984, Aspecten van staat en maatschappij in Africa: Recent Dutch and Belgian research on the African state, Leiden: African Studies Centre.

van Binsbergen, W.M.J., G. Hesseling \& F. Reyntjens (eds.), 1986, State and local community in Africa/Etat et Communauté locale en Afrique, Brussels: Cahiers du CEDAF/ASDOC geschriften, 2-3-4/1986. 


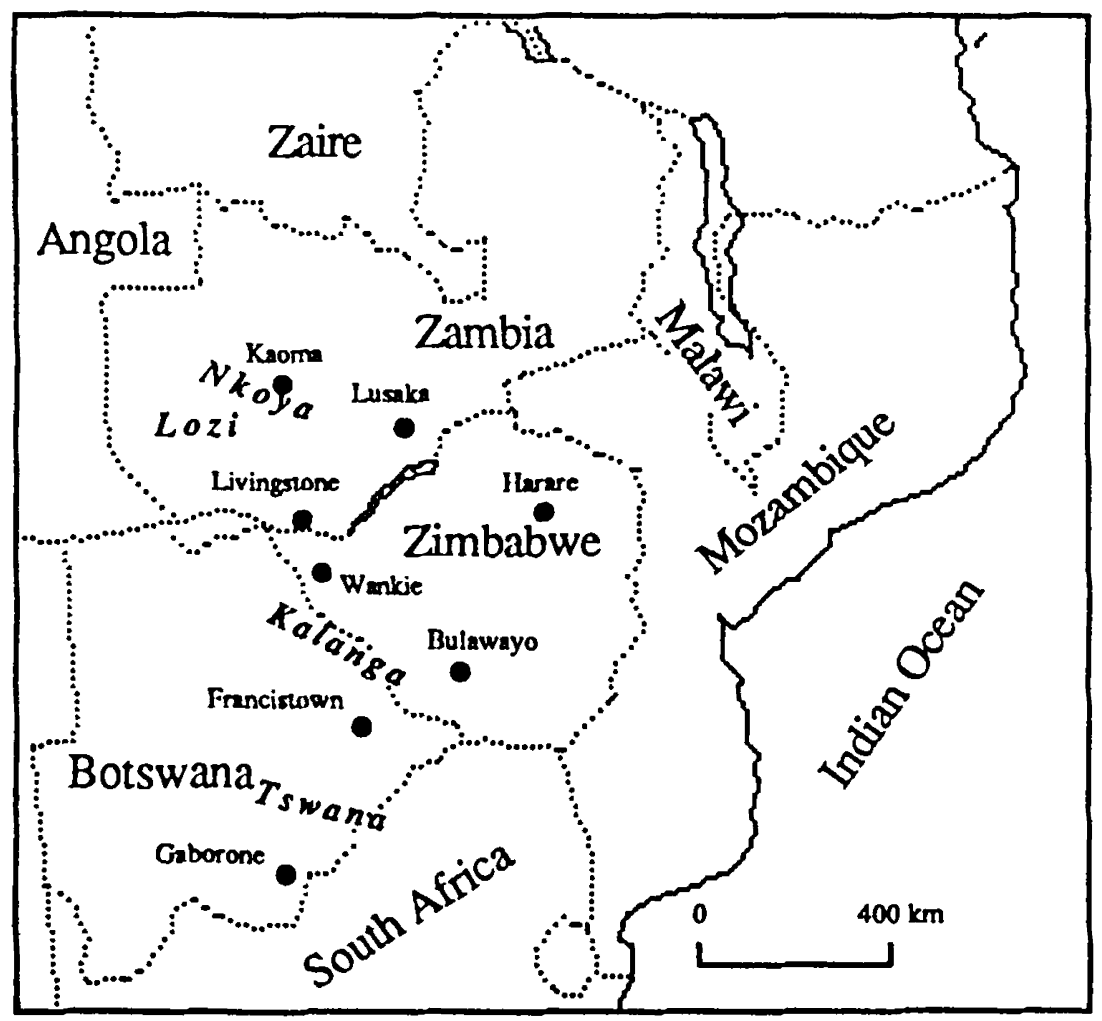

